\title{
Social Enterprise in Atlantic Canada
}

\author{
Doug Lionais
}

\author{
Cape Breton University
}

\begin{abstract}
This article explores the history and experience of social enterprise within Atlantic Canada. As part of the International Comparative Social Enterprise Models (ICSEM) research project, this article aims to describe the unique historical, contextual, and conceptual approaches to social enterprise in Atlantic Canada. Four case studies are provided to illustrate the diversity of social enterprise in the region. The article argues that the historical roots of social enterprise in Atlantic Canada can be found within the Antigonish Movement, and that the founding political economic vision of that movement can inform a progressive and transformative approach to social enterprise in the region.
\end{abstract}

\section{RÉSUMÉ}

Cet article explore l'histoire et la pratique de l'entreprise sociale dans les provinces de l'Atlantique. Écrit dans le cadre du projet ICSEM («International Comparative Social Enterprise Models »), cet article a pour but de décrire les approches historiques, contextuelles et conceptuelles envers les entreprises sociales propres aux provinces de l'Atlantique. II présente quatre études de cas afin d'illustrer la diversité des entreprises sociales de la région. L'article soutient que les racines historiques de l'entreprise sociale dans les provinces de l'Atlantique remontent jusqu'au Mouvement d'Antigonish, et que la vision politico-économique fondatrice de ce Mouvement pourrait sous-tendre une approche envers les entreprises sociales de la région qui soit progressiste et transformatrice.

KEYWORDS / MOTS CLÉS : Social enterprise; Atlantic Canada; Antigonish movement; ICSEM / Entreprise sociale; Provinces de l'Atlantique; Mouvement d'Antigonish; ICSEM 


\section{Lionais (2015)}

\section{INTRODUCTION}

The purpose of this article is to review the experience of social enterprise in the Atlantic Provinces. The article finds that there is not yet a strong conceptual attachment to social enterprise in Atlantic Canada. There are, however, a variety of approaches to social enterprise that we can observe in the region. The article will first look at the historical, contextual, and conceptual understanding and rooting of social enterprise in Atlantic Canada. Second, the article examines four illustrative cases-one from each Atlantic province-that demonstrate the diversity of social enterprise in Atlantic Canada. Third, I review the institutional supports (legislation, policy, and associations) for social enterprise in Atlantic Canada. Finally, I provide some comments on the present state of social enterprise in the region.

\section{HISTORICAL OVERVIEW}

For at least the last half century, Atlantic Canada has faced serious and persistent economic and social challenges. Donald Savoie (2006) argues that the Maritimes have been an underperforming region in Canada going back to confederation. Social enterprises often emerge in such geographies-where the market and the state have failed to provide adequate responses to social, economic, and environmental challenges (Amin, Cameron, \& Hudson, 2002; Hudson, 2011). It, therefore, should not be surprising that the history of social enterprise, which is broadly defined as a business operating for a social purpose, in Atlantic Canada is quite rich.

An organized economic movement around social enterprise in Atlantic Canada started in the 1920s with the Antigonish Movement (Dodaro \& Pluta, 2012). The Atlantic Provinces, at that time, had seen a reversal in their fortunes. Whereas in the nineteenth century, especially pre-confederation, the Maritime Provinces had been some of the most developed of the colonies, the twentieth century brought on decline. Important financial institutions moved offices to Ontario or Québec; other important industrial sectors were subject to the desires of absentee owners; labour unrest was common; and traditional maritime industries (shipbuilding, forestry, shipping trade) were rapidly declining. The economic hardships felt by the region fomented distrust and anger toward industrial capitalism and opened up the possibility for an alternative socioeconomic system. The Antigonish Movement was able to address this desire for a different approach.

Led by Moses Coady and Jimmy Tompkins, the Antigonish Movement established numerous cooperatives and credit unions across Atlantic Canada (and further afield). Based on ideas borrowed from Robert Owen and other utopian socialists as well as Catholic social thought, the Antigonish Movement advocated for cooperatives as the outcome of an adult learning process. Critically, Coady and Tompkins argued that people had the potential, and the responsibility, to take control of the economic resources of the region; they had the power to become, in Coady's (1939) words, "masters of their own destiny."

Coady and Tompkins employed an integrated program of development. The first step was educational; it involved the rollout of informational sources via pamphlets, bulletins, and circulating libraries, as well as leadership training. The cornerstones of the educational process were mass public meetings. The mass public meetings would then lead to the creation of smaller study clubs. The study clubs would then organize to create cooperative economic institutions (Dodaro \& Pluta, 2012). 


\section{Lionais (2015)}

The Antigonish Movement went through a rapid expansion in the 1930s radiating out from its home in Eastern Nova Scotia to all of the Atlantic Provinces and beyond. Attendance at mass meetings went from 14,856 people at 192 meetings in 1931, to 43,000 people at 470 meetings by 1936. Those meetings resulted in 173 study clubs being established in 1931 going up to 1,300 active study clubs by 1939. By the end of the 1930s the Antigonish Movement contributed to the creation of over 240 cooperative enterprises across Atlantic Canada. Cooperatives spanned several sectors, including fisheries, agriculture, finance (credit unions), housing, and retail (cooperative stores).

Success and momentum brought international recognition but also high expectations. The movement needed to deal with its success and expansion before it had a chance to put down roots (Dodaro \& Pluta, 2012). Although it thrived for a few decades, by the 1960s the movement was declining. Cooperative development stagnated and the second generation of leadership pragmatically focused on operational issues and, arguably, lost sight of the transformative vision of the movement. The radical vision of community control over the economy to bring "the full and abundant life to all" (Johnson, 1944, p. 9) was lost.

There are, however, many communities where the legacy of the movement lives on. Regions such as the Acadian communities of Cheticamp in Nova Scotia and the Evangeline Region of Prince Edward Island (see case study below) have maintained a thriving cooperative community and the cooperative sector remains relatively strong across the Atlantic Provinces.

Though the regional problem in Atlantic Canada continued in the postwar boom years, the issue became more acute again in the 1970s as the industries that sustained the economy, such as mining, steel, and pulp and paper, began to close down. At the same time governments (both federal and provincial) began to roll back the welfare state with cuts to social programs coming alongside efforts of deregulation and privatization. Numerous nonprofits were created in order to take care of those marginalized individuals who now found themselves without state support. Many of these organizations that ran on a redistributionist model began to adopt enterprising forms and behaviours in the latter part of the century as a means to secure more diverse and stable funding.

At the same time, a small number of community business corporations emerged across the Atlantic Provinces throughout the 1970s and 1980s. Building on the legacy of the Antigonish Movement, leaders such as Greg MacLeod sought ways of creating community-controlled enterprises but were not as attached to the cooperative form (MacLeod, 1986). Community corporations such as New Dawn Enterprises in Cape Breton (see case below) and the Great Northern Peninsula Development Corporation (GNPDC) in Newfoundland were established to create economic activity for the purpose of community development. These three models (coops, nonprofits, and community businesses) constitute the main social enterprise forms currently operating in Atlantic Canada.

More recently, a new form of "social" enterprise has emerged in Atlantic Canada. A spate of enterprises formed for the purpose of reviving local economies have appeared. However, rather than being endogenously driven, community organized and owned, they are characterized by wealthy benefactors and investors, sometimes expatriate community members, pursuing a private vision of community development. Some, such as Zita Cobb's Shorefast on Fogo Island, NL, use social enterprise organizational forms to achieve social and cultural goals (Shorefast Foundation, n.d.). Others, such as Glynn Williams's Authentic Seacoast in Guysborough, NS, employ traditional privately held business models (Bruce, 2012; Taber, 2013). 


\section{Lionais (2015)}

It is notable that the history of social enterprise activity in Atlantic Canada has often been against the grain of national and provincial policy. Policy approaches to regional problems have historically been top down, focusing on industrial sectors and employing a growth-pole, trickle-down model. Depleted communities outside of urban centres were largely left on their own. By the 1990s, however, the language of community economic development (CED) had penetrated provincial and federal governments. At the government level, CED was read to equate with endogenous, bottom-up approaches to economic development. Conceptual linkages to issues of social justice and alternative economic forms, however, were absent. Policies that followed tended to focus on entrepreneurship and innovation rather than social enterprise. This approach to CED fit well with the neoliberal policies of the time, which saw CED as an opportunity to download responsibility for development to communities themselves.

Within Atlantic Canada, Nova Scotia has been notable for pioneering a number of important tools and policies supportive of social enterprise. There are four particular policies that should be noted in this regard. First, the Community Economic Development Investment Fund (CEDIF) was established in 1999 to provide incentives for investors to place their money with local firms that qualify with the policy. While not specifically targeted toward social enterprise, many organizations have made use of this important financing mechanism. The CEDIF policy has been replicated in PEI (2012) and New Brunswick has similar legislation in process. Second, the CEDIF program was extended to fit into Nova Scotia's Community Feed-In Tariff (COMFIT) program; encouraging CEDIFs to operate in the renewable energy field. Third, in 2012, Nova Scotia created legislation for a community interest company $(\mathrm{CIC})$ form, allowing for the creation of companies with explicit community benefit purposes (Service Nova Scotia, 2012). Finally, Nova Scotia is in the process of introducing social impact bonds, although they are sometimes controversial (Joy \& Shields, 2013).

\section{CONTEXTUAL OVERVIEW}

The context of social enterprise in Atlantic Canada is characterized by economic and geographic isolation and historical legacies of alternative economic movements. The Atlantic Provinces have long been "have-not" provinces. Even Newfoundland and Labrador's recent elevation to "have" status, boosted by oil and gas developments, has not been felt by all residents. Newfoundland and Labrador still has one of Canada's highest unemployment rates and many residents seek work off island. The Atlantic region has experienced over a half century of chronically high unemployment levels due to prolonged industrial decline and federal politics that favoured central and western regions. Communities that have suffered the loss of traditional industries focus their efforts on saving the community. In this context, social enterprises are often viewed as mechanisms for reinvigorating local place-based economies. Economic salvation is connected to concerns for the survival of social and cultural identities linked to place. Further, the historical legacy of the Antigonish Movement informs the current practice of social enterprise. Community control of economic resources remains a central tenet of many Atlantic social enterprises.

\section{CONCEPTUAL OVERVIEW}

Atlantic provincial governments have not, despite some historical success, significantly acknowledged social enterprise. Nova Scotia established a Social Enterprise Working Group that produced a discussion paper on social enterprise in Nova Scotia (Nova Scotia Social Enterprise Working Group, 2011). They define social enterprise as "businesses or organizations operated for the purpose of tackling social, economic or environmental challenges" (p. 5). They also include five attributes of social enterprise to develop their definition: 


\section{Lionais (2015)}

1) democratic governance and a social mission, 2) profits are reinvested to advance the mission, 3) foster social and economic purposes, employ disadvantaged people, 4) blended (social and financial) return on investment, and 5) support social and economic integration for people confronting challenges. The Nova Scotia definition broadly shares elements of the EMES research network's definition (social mission, economic project, participatory governance) (Defourny \& Nyssens, 2012), though it tends to weigh more heavily on provision of social services (via integrating marginalized individuals). Within Nova Scotia policy, the community interest company (CIC) framework adopts a mission-driven business approach. Community interest companies are defined as "businesses whose primary purpose is the common good" (Service Nova Scotia, 2012).

In the New Brunswick context, a similar advisory group, the Advisory Committee on Social Enterprise and Community Investment Funds (SECIF), was struck in 2011 to examine social enterprise. SECIF was set in the context of a larger poverty reduction plan entitled Overcoming Poverty Together, which took a systematic approach to poverty. SECIF was one of three committees established to support the overall plan. They too produced a policy paper outlining the development of a social enterprise framework. SECIF describes social enterprise as a "form of business which occupies the space on the spectrum of economic activity between the non-profit sector and the for-profit sector" (Economic and Social Inclusion Corporation, 2012). The document sets out four criteria for social enterprise: 1) selling goods or services in the marketplace; 2 ) its primary purpose is to create social, environmental, and/or cultural value; 3 ) it uses a minimum of 51 percent of any profits to enhance programs and/or services to improve communities; and 4) it demonstrates evidence of the above.

Various institutional actors in Atlantic Canada have also defined the concept of social enterprise. The Atlantic Canada Council for Community and Social Enterprise (ACCSE) is an advocacy group (organized as a not-forprofit cooperative) established in 2011. ACCSE defines community and social enterprise as "organizations ... that operate like a business, produce goods and services for the market, but manage operations and direct surpluses in pursuit of social, environmental and cultural goals" (ACCSE, 2014). The nod toward some constraints on surplus distribution in ACCSE's definition also hints at the EMES' institutional approach to social enterprise. The Pond-Deshpande Centre at the University of New Brunswick defines social enterprise as "a business or organization, whether not-for-profit or for-profit, which has a strategic mission/purpose to address community, social, environmental challenges, issues and needs in the interest of the common good" (PondDeshpande Centre, 2015).

Interest in social enterprise has stimulated private sector responses as well. Common Good Solutions, in Nova Scotia, is a consulting firm that specializes in social enterprise development. They have partnered with other organizations such as Enterprising Non-Profits NS, an affiliate of Enterprising Non-Profits Canada (see Elson, Hall, Leeson-Klym, Penner, \& Andreas, in this issue). Common Good defines social enterprise as ventures that use revenue generating businesses to make positive change in their communities (Common Good Solutions, 2015).

Other than these examples of a broader perspective, social enterprise in Atlantic Canada operates as a set of independent sectors (cooperatives, nonprofits, etc.). While the cooperative sector tends to be fairly coordinated in each province with provincial cooperative associations advocating for the sector (and organizations specifically serving the Anglophone and Acadian groups in New Brunswick, PEl, and Nova Scotia), the nonprofit sector tends to be more loosely organized (often around common services). Newfoundland and Labrador and Nova Scotia, however, have provincial organizations that represent the sector (Nova Scotia's being quite recently organized). 


\section{Lionais (2015)}

As an emerging phenomenon in Atlantic Canada, social enterprises are defined (both in practice and conceptually) in a variety of ways. The legacy of the Antigonish Movement still resonates within some social enterprise. The social purpose of social enterprises that draw on this lineage is often rooted in community economic development and includes elements of democratic governance. Other social enterprises that have emerged in response to the decline of the welfare state focus on integrating marginalized peoples into the economic mainstream. Finally, we see more mainstream forms of enterprise brand themselves (or be branded by others) as social enterprises due to their efforts at local economic revitalization despite private ownership and private appropriation of surpluses. In each case, the concept of social enterprise is layered over preexisting forms and concepts (cooperatives and community business, nonprofits, and mainstream enterprise respectively). As the concept begins to take hold and policies are formed around social enterprise, such as Nova Scotia's CIC legislation, distinct new approaches may emerge.

\section{CASES OF SOCIAL ENTERPRISE IN ATLANTIC CANADA}

Four case studies have been selected, one from each province, to demonstrate the practice of social enterprise in Atlantic Canada.

\section{Analytical framework}

The framework for these cases builds upon the EMES indicators for social enterprise and Canadian-specific typologies developed by Peter Elson and Peter Hall (2013). The EMES indicators include 1) an economic project (production involving paid work and undertaking risk), 2) a social purpose (limited surplus distribution and initiative organized by a group of people or third sector organizations), and 3) participatory governance (autonomy, stakeholder participation, and decision making not based on capital ownership) (Defourny \& Nyssens, 2012). Elson and Hall (2013) employ a combined approach to social enterprise that takes into account both the legal/ownership structure and the social purpose of social enterprise.

The analytical framework also employs a political economic perspective developed by Ash Amin, Angus Cameron, and Ray Hudson (Amin et al., 2002; Hudson, 2011) that evaluates social enterprise in terms of its political relationship to mainstream capitalism. There are three distinct types of social enterprise identified in this classification:

1. Social enterprise as redistribution-welfare system. Supportive of a neoliberal approach, social enterprise redistributes wealth toward those marginalized by the mainstream.

2. Social enterprise as economic alternative. Wealth-creating enterprise based upon an alternate set of values and principles. Can work with the market and does not challenge the status quo.

3. Radical social enterprise. Disruptive enterprises that seek to radically transform the status quo and create a post-capitalist future.

The case studies will be structured as follows:

- A brief typology by legal structure, ownership, and social purpose;

- An overview of the social enterprise's activities and history;

- Business model and independence;

- Participatory governance; and

- Political economic position. 


\section{Lionais (2015)}

\section{Case: New Dawn Enterprises Limited Sydney, Nova Scotia}

\section{Typology}

Legal structure: Corporation limited by guarantee

Ownership: Non-shareholding corporation, social property

Purpose: Community development

\section{History}

New Dawn (New Dawn Enterprises Limited, 2015) was established in 1976. It is the outcome of several years of experimentation with organizational forms in response to community needs. The social entrepreneur at the heart of this development was Greg MacLeod, a catholic priest, scholar, and social activist. Prior to forming New Dawn Enterprises, MacLeod established a series of precursor community organizations. The antecedent organization to New Dawn was the Cape Breton Association for Cooperative Development, a nonprofit organization that addressed a local housing shortage. As the association developed, it found itself coming up against nonprofit regulations (under the Nova Scotia Societies Act) that barred it from engaging in business activity. MacLeod saw the need to find a new form of organization and established New Dawn Enterprises as a community purpose business.

New Dawn is incorporated as a corporation limited by guarantee (a non-shareholding corporation). As such it is a form of social property operated in trust of the community. In its articles of incorporation, New Dawn included a number of clauses that achieve an outcome similar to the form of a community interest company. For instance it includes clauses that create an asset lock, whereby the benefits of doing business accrue to the community as a whole and not to any individuals associated with the organization. The mission of the organization is to "engage the community to create and support the development of a culture of self-reliance" (New Dawn, 2015). It is operated in trust of its community. New Dawn's structure prohibits any distribution of surplus to individuals. All surpluses are reinvested in the organization and build the capacity of the organization to meet its social purpose.

New Dawn's early activities focused mainly on housing and other real estate ventures. For instance, one of the early projects (which was later sold) was to establish a number of dental clinics in the community. In response to a critical lack of dentists, New Dawn built and furnished a number of dental clinics in order to attract new dentists to the area. The project was very successful in filling this need in the community.

New Dawn continues to expand its real estate holdings with a mixture of residential and commercial real estate currently valued at approximately \$12 million. In 2013, New Dawn purchased a former high school and convent that occupies most of a city block. This project, intended to house a mix of social, cultural, and innovative organizations and businesses, is New Dawn's most ambitious to date. Other novel real estate projects include a partnered project that supports housing for persons suffering from mental illness (the SHIMI project) and a youth access centre for homeless and vulnerable young people (Access 808).

In addition to real estate, New Dawn has an education division offering vocational training programs and a healthcare division that provides home-care services and operates a guest home. New Dawn also has a division focused on community education and engagement. This division employs community development approaches to building community capacity and resilience. The community education and engagement division currently has five main activities: a citizen speaker series; a "films for change" series, a people's school, a support program for community leaders, and a collective impact community planning initiative. The education and engagement 


\section{Lionais (2015)}

division looks at the big picture and New Dawn's role in the community, while the other divisions focus on business operations.

New Dawn has also taken advantage of the Nova Scotia CEDIF program. Its CEDIF offerings, which have operated for about ten years, have been some of the most successful in the province. As a non-shareholding corporation, New Dawn had to establish a separate organization (now three separate organizations) to run the CEDIFs. Its first CEDIF-New Dawn Holdings (incorporated in 2003)—raised funds that were loaned to New Dawn Enterprises. The more recent CEDIFs-New Dawn Community Investment (2012) and New Dawn Innovation Fund (2013) - have been established as tools to invest in locally owned businesses rather than into New Dawn directly. Over the last 10 years New Dawn has raised close to $\$ 10$ million in CEDIF investments and has paid close to $\$ 1$ million in dividends to local investors.

New Dawn operates on a budget of approximately $\$ 7$ million dollars and employs over 175 people.

\section{Business model and financial independence}

New Dawn is primarily self-financed through the sales of its goods and services. While in some cases the government is a client (e.g., housing individuals for the department of community services), the organization does not receive any core funding from public or philanthropic giving.

\section{Participatory governance}

A volunteer board of directors governs New Dawn. The directors operate on a one-vote-per-person system and are elected from the membership. The membership, however, is limited, with only a few members who are not directors (past directors often remain as members). In practice, the board nominates and elects new board members from the community. There are no dedicated seats on the board for clients of the various services of New Dawn. Given this governance structure, New Dawn falls short of the participatory governance dimension of the EMES framework in that stakeholders are not involved in the decision-making.

\section{Political economic position}

New Dawn fits into the alternative wealth creation approach to the social economy. Although we can witness examples of the redistributionist approach and (to a lesser extent) the radical approach, New Dawn mainly operates as an enterprise operating for the social good but generally accepting the mainstream economy.

\section{Case: Saint John Community Loan Fund Saint John, New Brunswick}

\section{Typology}

Legal structure: Nonprofit corporation with charitable status

Ownership: Community

Purpose: Poverty reduction and labour market re-insertion

\section{History}

The Saint John Community Loan Fund (SJCLF) (Saint John Community Loan Fund, 2015) was established in 1999 in response to high levels of poverty in Saint John. The Urban Core Network proposed the idea for the fund: a nonprofit organization focused on poverty reduction. Community credit was a seen as a mechanism that could help people living in poverty start their own businesses or re-engage with the labour market. The SJCLF 


\section{Lionais (2015)}

mission is "to improve social conditions, promote economic independence, and foster entrepreneurship in our community" (Canadian CED Network, 2005).

Loans are made to individuals for business start up, employment, or shelter (e.g., rental down payments). The organization also provides literacy training and leadership training. The capital pool for loans comes in from community investors and donations (as a means to mitigate risk against losses). Over the last 15 years, the loan fund has made approximately 230 loans totalling over $\$ 369,000$. The average loan size is quite small, at just over $\$ 1,600$ per loan. The SJCLF claims this has saved the provincial government over $\$ 500,000$ in social assistance payments. As a nonprofit, the SJCLF operates for the public benefit. It has accumulated an equity balance of $\$ 165,345$ as of 2013 . SJCLF operates on a yearly budget of approximately $\$ 412,000$ dollars (2013).

In addition to loans, the SJCLF offers several training programs in developing life skills and financial literacy. Other programs support enterprise development for particular groups (e.g., women and youth). SJCLF programming focuses on community resource mobilization and community ownership. Based on a community economic development model, the SJCLF has increasingly become interested in social enterprise as a mechanism for achieving its mission.

Most recently the SJCLF has begun work on a social enterprise hub that would "foster creativity and entrepreneurship for poverty reduction" (SJCLF, 2015). The hub is intended to combine space for operating social enterprises (a café), incubator space for nascent social enterprises, and training space and offices for like-minded nonprofits. Through its social enterprise hub, the SJCLF is attempting to stimulate more social enterprise activity in its community.

\section{Business model and financial independence}

The SJCLF is financed through a variety of revenue streams. The largest source of revenues continues to be government sources, accounting for 45 percent of revenues. This includes contracts for services agreements as well as grants. The remainder is made up of various foundational contributions (philanthropic grants). The margin on loans distributed is not significant, as the interest charged does little more than cover the interest rate paid to investors.

\section{Participatory governance}

A volunteer board of directors governs the SJCLF.

\section{Political economic position}

The SJCLF fits into the redistributionist category. The purpose of the SJCLF is to help marginalized individuals find their way back into mainstream economic systems through business and employment loans. It is notable, that the SJCLF is now supporting social enterprise and therefore may represent a movement toward more alternative economic approaches. 


\section{Lionais (2015)}

\section{Case: Evangeline Cooperatives Wellington, Prince Edward Island}

\section{Typology}

Legal structure: Cooperative

Ownership: Second-tier cooperative

Purpose: Cooperative development

\section{History}

The Evangeline Region of Prince Edward Island is comprised of the French-speaking Acadian communities Wellington and Abrams Village and their surrounding areas between Bedeque Bay and Egmont Bay, west of Summerside. The current population is approximately 2,500 people (Statistics Canada 2012a, 2012b). Cooperative development in Evangeline began as far back as the 1860s but really took off in the 1930s with the influence of the Antigonish Movement. Through this movement, the Acadians of Evangeline created a number of credit unions, a fisherman's cooperative, a farmers' cooperative, as well as two consumer cooperatives. In 1977 the cooperatives of the region united to form the Conseil de la cooperation de l'île-du-Prince-Édouard. The Conseil was a second-tier cooperative that grouped the region's cooperatives into one functional body. The purposes of the Conseil were to promote cooperative education and development in Francophone PEI, to liaise with other Francophone cooperatives, and to control and coordinate the decision-making in cooperative concerns for Francophone PEI.

In 1999, the Conseil re-organized itself as the Conseil de développement coopératif de l'île-du-Prince-Édouard (CDC) (Conseil de développement coopératif, 2015) in order to take on a fully provincial mandate, although the majority of the cooperatives involved were still Evangeline based. Since 2010, the CDC has partnered with the Francophone economic development agency in PEI, RDÉE Île-du-Prince-Édouard, which is also based in the Evangeline region. The agreement means that the RDÉE is now in charge of the financial, material, and human resource management of the $\mathrm{CDC}$. The $\mathrm{CDC}$ includes 17 member cooperatives representing 8,500 members.

The Evangeline region is known as the world cooperative capital (Wilkinson \& Quarter, 1996), with the highest per capita cooperative memberships. In 1996 it was reported that there were 2.5 cooperative memberships per inhabitant (Wilkinson \& Quarter, 1996). Due to the 1999 reorganization of the CDC, it is more difficult to accurately calculate the per capita memberships, but the CDC reports that its member cooperatives have over 8,500 memberships, the vast majority of whom live in the Evangeline region (Conseil de développement coopératif, 2015).

The success of the cooperative movement in the Evangeline region has led to "cooperative burnout" in the past, whereby the numerous cooperatives were finding it difficult to keep people on their boards and committees due to competing demands. Partly to deal with this, and partly because of losing their main funding source, the Conseil looked into a number of different options for restructuring. After completing a study in 1995 and visiting the Mondragon cooperatives in Spain, the board of the Conseil recommended a move to a Mondragon-style corporate structure with one board overlooking and administering all of the cooperatives. The member cooperatives rejected this proposal. Subsequently, the organization chose to reorganize as a more provincially mandated organization with more secure funding, as represented by the move to the CDC and the partnership with RDÉE.

Over the past few decades, the CDC has helped build a strong cooperative framework in the region. 


\section{Lionais (2015)}

\section{Business model and financial independence}

The Canadian Cooperative Council and its cooperative memberships fund the CDC. Operational funding from the Canadian Cooperative Council suggests that this organization is not financially independent and therefore does not fit well with the EMES approach to social enterprise. However, the debate regarding moving to a Mondragon-style cooperative corporation in the 1990s suggests there was potential for the Evangeline Cooperatives to organize themselves collectively as a social enterprise at that stage.

\section{Participatory governance}

The $C D C$ has a board of directors that represent the member cooperatives. Currently the CDC has one of 13 seats on the board of directors of the RDÉE.

\section{Political economic position}

The CDC fits into the alternative wealth creation category.

\section{Case: St. Anthony Basin Resources Incorporated (SABRI) St Anthony, Newfoundland and Labrador}

\section{Typology}

Legal structure: Non-shareholding corporation

Ownership: Non-shareholding corporation, community property

Purpose: Resource management for community purpose

\section{History}

St. Anthony Basin Resources Incorporated (SABRI) (St. Anthony Basin Resources Incorporated, 2015) was established in the Great Northern Peninsula region of Newfoundland and Labrador. The region has a population of approximately 4,500 people. Like many rural communities in Newfoundland and Labrador, St. Anthony and the Great Northern Peninsula region were economically devastated by the cod moratorium in 1992. To compensate for the loss of the cod fishery, many fishers moved into alternative fisheries such as shrimp and crab. In 1997, the Department of Fisheries and Oceans drastically increased the allowable catch of shrimp. While most of the new quota was allocated to private interest (individual harvesters) a special allocation of 3,000 tonnes of additional catch was given to the St. Anthony region of the Great Northern Peninsula. SABRI was organized as a nonprofit social enterprise in order to manage this special allocation for the benefit of the community as a whole. Its mission is to "administer a 3,000 metric tonne allocation of Northern Shrimp on behalf of the communities from Big Brook to Goose Cove, in a manner resulting in expansion of the region's economic base and improved employment opportunities in harmony with a rural setting and lifestyle" (St. Anthony Basin Resources Incorporated, 2015).

The special allocation was a means for the government to use quota as a mechanism for community economic development rather than simply sectorial (fisheries) development. SABRI initially leased out the rights to the community's quota with a requirement that the catch be landed and processed in St. Anthony. In the longer term, SABRI sought international partners to manage the catch, eventually attracting a number of partners with the commitment to build an advanced processing plant in St. Anthony with $\$ 12$ million in investments. 


\section{Lionais (2015)}

All surpluses generated by SABRI are invested back into the community through business expansion opportunities and social and community development. SABRl's business expansion activities are in response to local and international market demand (White \& Hall, 2013). For instance, SABRI is investing in a salt fish market due to demands in Iceland and Newfoundland and Labrador. In terms of community development, SABRI undertook an oral history project to capture stories of cultural and historical significance. Additionally, some of SABRI's projects have aspects of both economic expansion and community development. For instance, it started a muscle farming initiative that was intended to be a new economic opportunity, but tight competition has meant the project operates at a loss. SABRI, however, continues to run the venture because of the local employment it generates and the positive impact it has in supplying the local tourism sector (White \& Hall, 2013).

SABRI is an example where the EMES definition of social enterprise does not completely fit. In particular, SABRl's development comes from a top-down approach where the federal government created the space for SABRI by allowing the special allocation of quota. It is not an organization that was formed by a group of citizens; rather it was formed as a response to, and under the direction of, government policy. Here we see one of the productive roles of government in creating and supporting place-based social enterprise.

\section{Business model and financial independence}

SABRl's primary activity is the management of fishing quota based on the market. The royalties and revenues it earns form its fishing activities are re-invested back into the purpose of the organization. SABRI is financially independent.

\section{Participatory governance}

A volunteer board of directors made up of representatives of different organizations and stakeholders in the region governs SABRI. Representation on the board comes from fishers, plant workers, local community development agencies, and members of the local community.

\section{Political economic position}

SABRI fits into the alternative wealth creation category. 


\title{
Lionais (2015)
}

\section{INSTITUTIONS}

Table 1 outlines some of the key pieces of legislation, policy, and associations present in the Atlantic Provinces that impact social enterprise

\section{Table 1 - Key Institutions for Atlantic Canada Social Enterprise}

\author{
Key legislation and policy \\ Associational presence

\section{Nova Scotia} \\ Co-operative Associations Act \\ Companies Act \\ Societies Act \\ Community Economic Development Funds \\ Community Interest Companies \\ Social Impact Bonds

\section{New Brunswick} \\ Co-operative Associations Act of New Brunswick \\ Companies Act (New Brunswick) \\ Community Nonprofit Organizations Secretariat

\section{Prince Edward Island \\ Charities Act \\ Co-operative Associations Act \\ Community Development Equity Tax Credit Act/Community \\ Economic Development Business Program} \\ Companies Act \\ Nova Scotia Co-operative Council \\ Conseil coopérative acadien de la Nouvelle-Écosse \\ Community Sector Council of Nova Scotia \\ Nova Scotia Social Enterprise Working Group \\ Co-operative Enterprise Council of New Brunswick \\ Conseil acadien de la coopération (Nouveau-Brunswick) \\ Conseil de développement coopératif de l'Île-du-Prince- \\ Édouard \\ Prince Edward Island Co-operative Council
}

\section{Key legislation, policy, and government supports}

Like other provinces across Canada, the Atlantic Provinces each have a similar set of legislation that frames the local context for social enterprise. In each province, organizations can form under three specific legal structures: incorporated companies, cooperatives, and nonprofit societies. In addition to these common structures, some provinces have unique forms of legislation and policy that impact social enterprise. Below, I explore both the common legal frameworks and the more unique policies that exist.

\section{Companies Act}

The companies/corporations acts of Atlantic Provinces allow for the creation of conventional share-ownership corporations. While social enterprise can take advantage of this aspect of incorporation, many organizations use a nonprofit form of corporation for the social economy. In Nova Scotia, nonprofit corporations are found in the portion of the Companies Act called a company limited by guarantee. Companies limited by guarantee are formed by members whose liability is limited to a specified amount (usually fairly nominal), which is to be used 


\section{Lionais (2015)}

to cover the debts of the organization upon winding up of the company. Companies limited by guarantee may or may not have shares. Companies limited by guarantee must include a set of articles of incorporation with their registration. It is within these articles that companies limited by guarantee can often institutionalize their social purpose. The companies (corporations) acts of the other Atlantic Provinces similarly allow for nonprofit corporations. In Newfoundland and Labrador, nonprofit corporations use articles of association to establish themselves within the Corporations Act. In PEl and New Brunswick, nonprofit corporations are incorporated via letters patent.

\section{Co-operatives Act}

The provincial cooperatives acts in Atlantic Canada provide a legal framework for organizations that are owned by and provide service to their members. Democratic equality of members and proportional distribution of surplus are enshrined within the act. In Nova Scotia, organizations can be limited by shares or, similar to a company limited by guarantee, limited by membership. A cooperative limited by membership is commonly called a nonprofit cooperative. Nonprofit cooperatives are typically more limited in accessing financial capital, as they cannot raise capital through selling shares to members. The cooperative acts of the other Atlantic Provinces are similar to that of Nova Scotia.

\section{Societies Act}

The Societies Act or Charities Act is used to incorporate an organization that has a benevolent or social purpose, but is barred from engaging in trade and business. Societies are barred from having any share capital and issuing dividends to members. The societies/nonprofit/charities acts of the other Atlantic Provinces are broadly similar.

Beyond this common set of legal forms, there are three relatively novel policy supports for social enterprise in Atlantic Canada. Nova Scotia, however, is a leader in supportive social enterprise policy.

First, in 1998, the Nova Scotia government, building on its successful equity tax credit program, established the Community Economic Development Investment Fund (CEDIF) program. The equity tax program offered a 30 percent tax credit to investors who invested in Nova Scotia businesses. The CEDIF policy built on the tax credit (now 35 percent) by pre-approving CEDIF holdings as RRSP eligible and allowing CEDIF firms to solicit investments publicly. Furthermore, a community could establish a CEDIF to raise funds to invest in other businesses. For the investor, CEDIFs offered an attractive incentive to invest locally. A CEDIF investment receives a 35 percent provincial tax credit and must be held for five years. A further 20 percent tax credit is available if investors roll their investment over for a subsequent five-year period and another ten percent credit is available for a third five-year period. RRSP eligibility also provides an incentive to the investor. Finally, while most CEDIFs do not expect that value of shares to rise, some pay a dividend. The New Dawn CEDIFs (New Dawn manages three related CEDIF funds, which are profiled below) for instance, has paid out dividends ranging from 3 percent to 4.3 percent over the past ten years. While the CEDIF program was not specifically designed with social enterprise in mind, it has become a common tool for raising finances for many shareholding social enterprises in Nova Scotia.

The Government of PEI has replicated the Nova Scotia CEDIF program through the Community Development Equity Tax Credit Act, which it administers under its Community Economic Development Business (CEDB) program. Its objective is to "facilitate local investment in Prince Edward Island businesses, with the ultimate aim of stimulating rural community development" (PEI, 2014). PEl, however, places different restrictions on eligible CEDB investments. For instance, in PEI, the program limits investment into small businesses with caps on 


\section{Lionais (2015)}

financial resources (maximum $\$ 25$ million in assets or revenues) and employment size (maximum 100 full-time employees).

Second, Nova Scotia recently introduced Community Interest Companies (CIC). Legislation was passed in 2012 though final regulations have yet to be introduced. CICs are companies that serve a community purpose, meaning they create benefits for society at large or a segment of society beyond those persons directly related to the company. Community purpose can include providing health, social, environmental, cultural, and educational services but excludes political purposes. The assets of a $\mathrm{CIC}$ are considered "locked" into the community they serve; they cannot be sold off upon dissolution but must be transferred to another community purpose entity (such as a charity or other $\mathrm{CIC}$ ). Where a $\mathrm{CIC}$ has shares, there are limits to how much dividends can be paid to shareholders. In order to maintain their $\mathrm{ClC}$ status, a company must produce a community interest report each year demonstrating its adherence to the community purpose set out in its memorandum of association. There is no tax advantage to incorporating as a ClC. ClCs will be seen as an alternative to charities, as they can raise equity financing and have more flexibility than charities in pursuing their social purpose.

Third, in 2013, Nova Scotia announced that it would be the first Canadian jurisdiction to produce a Social Impact Bond (SIB). SIBs are incentives provided to the private sector or the social economy to address social issues. The private organization must front the costs of the intervention (building homes for homeless people, for instance), and when they have demonstrated success in addressing the issue, the government repays the investment plus a prescribed surplus. SIBs are somewhat controversial as they are often seen as further downloading of government provision and the privatization of social care (Joy \& Shields, 2013). However, some social enterprises will likely see SIBs as another unique financing tool. As with CICs, Nova Scotia has not yet set out the regulations for SIBs.

\section{CONCLUSION}

Social enterprise in Atlantic Canada is an emerging phenomenon that makes use of a variety of approaches, is rooted to a legacy of community development, and is set in a context of a chronically weak economy. Social enterprise in Atlantic Canada tends to focus on wealth redistribution (in the case of the SJCLF) or wealth creation (New Dawn, SABRI, and the Evangeline Cooperatives). Atlantic social enterprise draws on distinct histories and forms, including cooperatives, nonprofits, and community business. A common theme in Atlantic social enterprise is addressing chronic social-economic issues, such as poverty and unemployment, in particular communities.

From a political economy perspective, the cooperatives of the Antigonish Movement and the community businesses rooted in that history were established with radical, transformative ideals. However, in practice, most have evolved into alternative, principle-based, wealth creating enterprise rather than transformational enterprises. While economic depletion can open the potential for radically alternative economic approaches, in practice, the enterprises have to exist in the harsh context of a chronically weak market economy. These historical roots in a radical alternative contrast with a practice of alternative wealth creation and institutional (government) approaches to social enterprise that are based on redistribution.

Historically the examples of social enterprise have existed under different terminologies (cooperatives, nonprofits, community business, etc.). This raises the question of what the language of social enterprise adds to 


\section{Lionais (2015)}

these pre-existing forms. For whom does social enterprise, as a concept, work? A redistributionist approach to social enterprise works well for cash-strapped governments looking to sell the downloading of social services to communities. However, there are alternative approaches.

If it is to be an effective practice for change, the term needs to wrestle with its political dimensions where the social purpose falls in the public sphere (see Hillenkamp \& Laville, 2014). Re-engaging with the political aspect of social enterprise, in the Atlantic Canada context, raises the possibility of reviving the roots of the Antigonish Movement, which are linked to a vision of fundamental and transformational change for a region that has, more often than not, suffered from the impacts of global capitalism.

Social enterprise, conceptually and in practice, continues to gain ground in the Atlantic Region. New policies in support of social enterprise have been established in Nova Scotia. However, we have yet to see what fruit those policies may bear and what direction social enterprise may take.

\section{REFERENCES}

ACCSE. (2014). About - ACCSE/CAESC. URL: www.http://accse.ca/about/ [July 4, 2014].

Amin, A., Cameron, A., \& Hudson, R. (2002). Placing the social economy. London, UK: Routledge.

Bruce, A. (2012). Breathing new life into old town. Atlantic Business Magazine, November/December 2012, 91-94. Canadian CED Network. (2005). Saint John community loan fund. URL: http://ccednet-rcdec.ca/files/ccednet/ SJCLF-E.pdf [May 4, 2015].

Coady, M. (1939). Masters of their own destiny. New York, NY: Harper and Row.

Common Good Solutions. (2015). Common Good Solutions. URL: http://commongoodsolutions.ca/ [May 4, 2015].

Conseil de développement coopératif. (2015). Conseil de développement coopératif. URL: http://www.rdeeipe .net/cdc/ [April 22, 2015].

Defourny, J., \& Nyssens, M. (2012). The EMES approach of social enterprise in a comparative perspective [working paper No. 12/03]. URL: http://www.emes.net/what-we-do/publications/working-papers/theemes-approach-of-social-enterprise-in-a-comparative-perspective/ [April 15, 2015].

Dodaro, S., \& Pluta, L. (2012). The big picture: The Antigonish Movement of eastern Nova Scotia. Montréal, QC: McGill-Queen's University Press.

Economic and Social Inclusion Corporation. (2012). Learning and earning: Building a social enterprise policy framework. Fredericton, NB: Advisory Committee on Social Enterprise and Community Investment Funds (SECIF).

Elson, Peter, \& Hall, Peter. (2013). Plowing the fields: Provincial surveys of social enterprises in Canada. Paper presented at the 4th EMES International Research Conference on Social Enterprise. Liege, Belgium: University of Liege. URL: http://www.sess.ca/english/wp-content/uploads/2014/01/Elson-and-HallEMES-2013.pdf [April 2, 2015].

Hillenkamp, I., \& Laville, J.-L. (2014). Theory of the social enterprise and pluralism: The social enterprise of the solidarity type. Paper presented at the Western ICSEM Symposium, La Roche-en-Ardenne, BE: EMES Network.

Hudson, R. (2011). The regional problem and the social economy: Developmental potential and limits. Paper presented at the Conference on Sustainable Community Business, July 13-15, 2011. Sydney, NS: Cape Breton University,

Johnson, Harry G. (1944). The Antigonish Movement: A Lecture to the Students of Acadia University. Antigonish, NS: Extension Department, St Francis Xavier University. 


\section{Lionais (2015)}

Joy, M., \& Shields, J. (2013). Social impact bonds: The next phase of third sector marketization? Canadian Journal of Nonprofit and Social Economy Research, 4(2), 39-55.

MacLeod, G. (1986). New age business: Community corporations that work. Ottawa, ON: Canadian Council on Social Development.

New Dawn Enterprises Limited. (2015). About New Dawn. URL: http://newdawn.ca/about/ [May 4, 2015].

Nova Scotia Social Enterprise Working Group. (2011). Social enterprise in Nova Scotia: Concepts and recommendations. (Discussion Paper). Halifax, NS: Nova Scotia Social Enterprise Working Group.

PEI. Department of Finance and Municipal Affairs. (2014). Community economic development business. Charlottetown, PEl: Department of Finance and Municipal Affairs. URL: www.gov.pe.ca/cedb/ [April 2, 2015].

Pond-Deshpande Centre. (2015). Social enterprise portal. URL: http://www.ponddeshpande.ca/en/socialenterprise/ [May 4, 2015]

St. Anthony Basin Resources Incorporated. (2015). SABRI Mission. URL: http://www.sabrinl.com/mission.html [April 7, 2015].

Savoie, D.J. (2000). Community economic development in Atlantic Canada: False hope or panacea. Canadian Institute for Research on Regional Development: Maritime Series, 7.

Savoie, D.J. (2006). Visiting grandchildren: Economic development in the Maritimes. Toronto, ON \& Buffalo, NY: University of Toronto Press.

Service Nova Scotia. (2012). New opportunities for social entrepreneurs. Halifax, NS: Government of Nova Scotia. URL: http://novascotia.ca/news/ release/?id=20121128010 [April 2, 2015].

Shorefast Foundation. (n.d.). Our foundation. URL: http://shorefast.org/about-us/overview/ [April 2, 2015].

Saint John Community Loan Fund. (2015). SE hub. URL: http://loanfund.ca/sehub/ [April 28, 2015].

Statistics Canada. (2012a). Wellington, Prince Edward Island (Code 1103029) and Lot 16, Prince Edward Island (Code 1103028) [Table]. Census Profile. 2011 Census. Statistics Canada Catalogue no. 98-316-XWE. URL: http://www12.statcan.gc.ca/census-recensement/2011/dp-pd/prof/index.cfm?Lang=E [April 22, 2015]. Ottawa, ON: Statistics Canada.

Statistics Canada. (2012b). Abrams Village, Prince Edward Island (Code 1103027) and Lot 15, Prince Edward Island (Code 1103026) [Table]. Census Profile. 2011 Census. Statistics Canada Catalogue no. 98-316XWE. URL: http://www12.statcan.gc.ca/census-recensement/2011/dp-pd/prof/index.cfm?Lang=E [April 22, 2015].

Taber, J. (2013). Who is the Toronto millionaire buying up businesses in rural Nova Scotia? Globe and Mail. URL: http://www.theglobeandmail.com/news/national/a-multimillionaires-coastal-town-revival/ article13331176/ [April 2, 2015].

White, K., \& Hall, H. (2013). St. Anthony basin resources incorporated (SABRI): Expanding regional social and economic benefits. St John's, NL: Memorial University.

Wilkinson, P., \& Quarter, J. (1996). Building a community controlled economy: The Evangeline Co-operative experience. Toronto, ON: University of Toronto Press.

\section{ABOUT THE AUTHOR / L' AUTEUR}

Doug Lionais is Associate Professor in the MBA CED program at Cape Breton University. Email: Doug_Lionais@cbu.ca. 